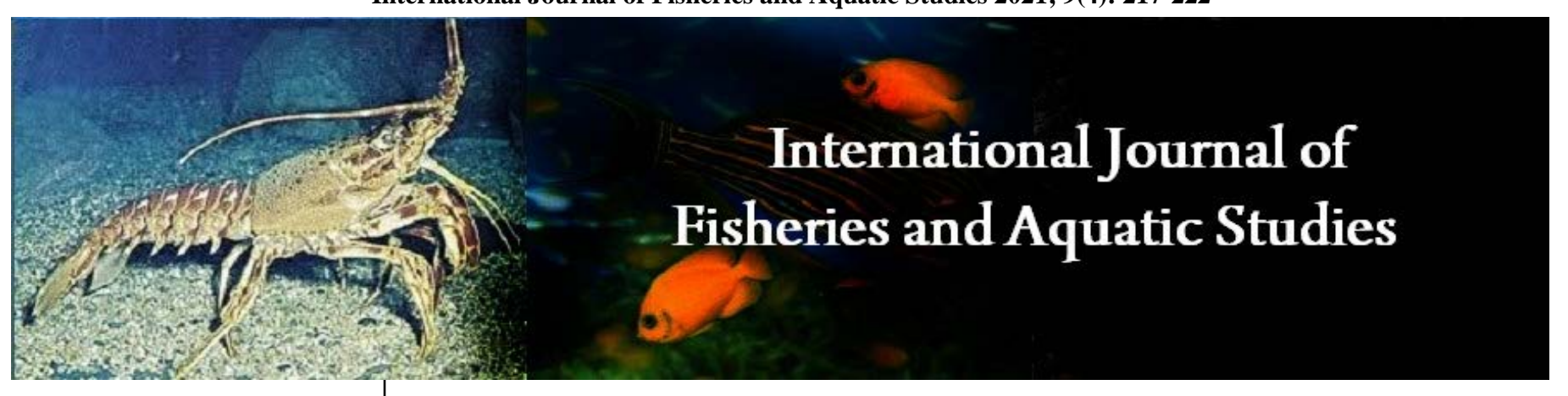

E-ISSN: 2347-5129

P-ISSN: 2394-0506

(ICV-Poland) Impact Value: 5.62

(GIF) Impact Factor: 0.549

IJFAS 2021; 9(4): 217-222

(C) 2021 IJFAS

www.fisheriesjournal.com

Received: 10-05-2021

Accepted: 12-06-2021

\section{AK Mandal}

Associate Professor,

Department of Economics and

Sociology, Patuakhali Science

and Technology University,

Dumki, Patuakhali, Bangladesh

Corresponding Author:

AK Mandal

Associate Professor,

Department of Economics and

Sociology, Patuakhali Science

and Technology University,

Dumki, Patuakhali, Bangladesh

\section{Value chain analysis of dry fish marketing in coastal belt of Bangladesh}

\author{
AK Mandal \\ DOI: https://doi.org/10.22271/fish.2021.v9.i4c.2538
}

\begin{abstract}
Dried fish marketing plays an important role in the economy of Bangladesh, contributing to increased gross domestic product, diversification of the economy and increased employment opportunities. The aim of this study to examine the existing marketing system, identify different marketing channel and to estimate the value addition of different actors who are involved in the marketing chain of dry fish. Multistage stratified simple random sampling technique has been used in selecting the sample and the total 120 respondents were selected from the Patuakhali and Coxs Bazar for the study. Data were collected through interview schedule. The study found that the process of preparing dried fish starts in October and end in February or March. Dry fish processor followed horizontal and vertical drying method. The study also revealed that seven channels were identified in dry fish marketing. Dry fish processors sold $(90 \%)$ their dried fish to dry fish aratders. The per quintal average marketing cost was estimated of dried fish in different actors like dried fish processor for Tk. 3942, arathder for Tk. 53.68, wholesaler for Tk. 1485 and retailer for Tk. 110. Value addition of the dried fish processor, arathder, wholesaler and retailer were calculated Tk. 4935, Tk. 1237.32, Tk. 2019, and Tk. 4862 per quintal respectively.
\end{abstract}

Keywords: dry fish, coastal belt, marketing systems and value addition

\section{Introduction}

Dry fish is an important source of protein in Bangladesh ${ }^{[1,2]}$ and plays a major contribution in providing nutrition's for the poor as well as economically disadvantaged people ${ }^{[2]}$. The nutrient composition of fish varies widely across species, particularly for micronutrients. Iron content ranged from 0.34-19 mg/100 g raw, edible parts; zinc from 0.6-4.7 mg/100 g; calcium from 8.6-1900 mg/100 g; vitamin A from 0-2503 $\mu \mathrm{g}$ RAE/100 g; and vitamin B12 from 0.50$14 \mu \mathrm{g} / 100 \mathrm{~g}{ }^{[3]}$. Fish process activity through drying is most important in the coastal area of Bangladesh. In the coastal belt, fish drying generally starts in October and ends in March. In some coastal villages, fish drying process starts in early September and lasts till the end of May ${ }^{[1]}$. Dried fish has more demand both in domestic and world market. Bangladesh has exported 56 crore BDT dried fish during 2018-2019 ${ }^{[4]}$. The product of dried fish is easily transportable, marketable and storable ${ }^{[5,6]}$. Sun drying is a least expensive method of fish preservation and solar energy is used for the removal of moisture from the fish ${ }^{[7]}$. The product of dried fish is easily transportable, marketable and storable ${ }^{[6]}$ and have good potential in India, Sri Lanka, Hong Kong and Singapore ${ }^{[8]}$. In Bangladesh most of the market samples become slightly off odour and some already loses the shelf-life where rancid odor and bitter taste are developed ${ }^{[9]}$. The marketing system operates through a set of intermediaries performing useful commercial functions in a chain from the producers to the final consumers ${ }^{[10]}$. However, the fish market structure varies from area to area, but in general it can be of four type's viz. primary, secondary, higher secondary and final consuming market ${ }^{[11]}$. The price of dried marine fish varies with the availability, size and quality of the fish species ${ }^{[12]}$. Dry fish is one of the traditional food items in Bangladesh. In different cultural programs, we prefer dry fish as a part of celebration ${ }^{[13]}$. But high priced fish demanded high marketing cost resulting higher marketing margin and profit compared to low-priced fish ${ }^{[14,15]}{ }^{1}$. We know that many actors are involved in dry fish marketing. The net profit of bepari, arathdar, wholesaler and retailer was $5.98 \mathrm{Tk} / \mathrm{Kg}, 6.26 \mathrm{Tk} / \mathrm{Kg}, 7.30 \mathrm{Tk} / \mathrm{Kg}$ and $8.10 \mathrm{Tk} / \mathrm{Kg}$ respectively ${ }^{[15]}$. Considering these coastal belts dry fish market was favored and selected for the present study. 
The study examine the existing marketing system, identify different channel of dry fish marketing and to estimate the value addition of producers and traders involved in the marketing chain of dry fish in coastal belt in Bangladesh.

\section{Materials and Methods}

\section{Selection of the study area}

Dry fish are largely produced in the coastal districts of Patuakhali and Cox's Bazar which is the southern region of Bangladesh. On the concentration of production and marketing, Patuakhali and Cox's Bazar was selected as the study area.

\section{Sampling procedure}

Multi-stage stratified simple random sampling technique was followed for the selection of district, upazila, and market for the collection of data. Then the population from upazila and market were grouped into different strata like; farmer, dry fish processor, arathder, wholesaler (bepari), and retailer and the simple random sampling technique was used for drawing the desired sample from each strata.

\section{Sample size}

A total of four major chain actors; dry fish processor, arathder, wholesaler and retailer were involved in the dry fish marketing in the study area. From two districts (Patuakhali and Cox's Bazar) 120 respondents was selected as a sample on the basis of concentration of production and marketing of dry fish. At each district, production and marketing information was collected from 20 dry fish processors, 10 arathders, 10 wholesalers (beparies) and 20 retailers during July 2019-September 2019.

\section{Analytical Technique \\ Gross margin analysis}

Gross margin is the difference between the gross return and the variable cost of any business. Here, only the variable cost was taken in account to calculate the gross margin. Gross margin can be calculated by following formula

Gross margin $=$ Gross return - Total variable cost

Where, Gross return $=$ Sold quantity of dried fish $(\mathrm{Kg}) \times$ Unit price of dried fish $(\mathrm{Tk} / \mathrm{Kg})$

Total variable cost $=$ Sum of cost of all variable inputs

\section{Total revenue, net income, and net margin/value addition}

The economic analysis has been performed for measuring the costs and margins of business operations at different stages of value chain. The economic costs and benefits of individual chain actor were analyzed using the following formula.

Total revenue of traders $(\mathrm{Tk} / \mathrm{Kg})=\sum\left(\mathrm{Q}_{\mathrm{i}} \times \mathrm{P}_{\mathrm{i}}\right)$

Where, $\mathrm{Q}_{\mathrm{i}}$ is the total quantity of ${ }^{\mathrm{i}}$ th traders of dry fish products sold, and $\mathrm{Pi}$ is the price of ${ }^{\mathrm{i}}$ th traders of dry fish product.

Total cost to a chain actor $(\mathrm{Tk} / \mathrm{Kg})=$ Fixed cost + Variable costs

The net income of an actor was calculated by deducting total cost from total revenue, i.e.

Net income $(\mathrm{Tk} / \mathrm{Kg})=$ Total revenue - Total cost

Net margin/Value addition $(\mathrm{Tk} / \mathrm{Kg})=$ Gross margin Marketing cost

\section{Results and Discussion \\ Marketing systems of dry fish \\ Dry fish marketing in Kuakata}

At Kuakata, thousands of fishermen catch fish about 58,000 tons from the sea in every year. Mainly some fishermen catch fish from the sea in winter season for making dry fish. But Kuakata has no modern fish drying plant and traditional methods are still being used here. Most of the dry fish qualities are not standard. During bad weather or the rainy season, dry fish become damp and begin to rot. In such a situation, the fish, caught sometime earlier, are again dumped into the sea. Moreover, fishermen often use harmful insecticides to prevent the rotting of dry fish and rely on nature. Fishermen make five to six feet high platforms with bamboo and sticks and spread bamboo or grass mats on them to dry the fish. The fish drying area is known as 'shutki palli'. Dry fish are always available here at a cheap rate in these areas during the fish drying season. Traders say that various species of fish such as Rupchanda, Kangot, Shaplapata, Shark, Koral and others are dried here. The small species of fish are Loitta, Chhuri, Tulardadi, Bairagi, Failsha, Chapli, Shellfish, Prawnk Lobster, Kuichafish, Gusha fish, shrimp, tiger-shrimp, Dhalsa and Bhula are called white fish and locally sold at Tk. 60 to Tk. 80 per kg.

\section{Dry fish marketing in cox's bazar}

The coastal district of Cox's Bazar produces dried fish, worth around Tk 300 crore every year, with about one lakh people directly involved in the trade. Big dry fish marketing centers are located in Chittagong and Cox's Bazar. Wholesalers give advance money to the fishermen to book the producer and supply the fish to the marketing centers at the end of the fish drying season. The fish is also exported to different countries after meeting local demand. The process of preparing dried fish starts on October in Naziratek, Sonadia Island under Maheshkhali upazila, Sundaripara Chhanua riverbed in Pekua upazila, Teknaf, Shamlapur, St Martin's Island and Baro Ghop in Kutubdia upazila. If the weather remains favorable, the process continues till February and March next year. Naziratek at the confluence of the Bay of Bengal near Cox's Bazar airport has become the largest shutki mahal of the country in last one decade. Naziratek Shutki Mahal has been built on 200 acres of land. Around 2,000 traders have invested here and establish more than 50 wholesale shops.

\section{Fish drying system in the coastal belt}

Sun drying is the exclusive method of fish drying. There are two techniques of sun drying:

Horizontal drying: The main bulk of the catch consists of small fish which are dried on horizontal wooden racks raised about one meter above the ground. The fish are placed on mats and turned occasionally to prevent sticking to the mat.

Vertical drying: Big fishes like Loittya, Chhuri, Boal and Indian salmon are typically dried hanging from vertical wooden racks. Some small stingrays are sliced into longitudinal strips which remain attached to the tail base, and the whole ray is hung by the tail from a vertical rack to dry. However, some rays are cut up entirely and the slices are dried on horizontal racks. A typical drying yard consists of a fenced area with a small house at one end where the fishermen live. One typical yard was paced out by the staff at about 13 meter by 35 meter, but the dimension of yards varies widely. About $75-90 \%$ of a drying yard is covered by fish drying in a horizontal position. Typically the fish are dried on mats which are either placed to horizontal racks or directly on the ground. 


\section{Fish drying season}

In the study area fish drying generally starts in July and end in January. Peak drying is observed September-October because of this season, sufficient sunlight was available throughout the day. Fish drying activities mainly depends on the raw materials availability, weather condition and market demand.

\section{Method of traditional sun drying}

The traditional fish drying process completed in some steps. The following steps normally followed in commercial fish drying.

\section{Collection of raw fish}

Most of the dry fish processor collects raw fishes from local fish market and directly from fisherman and other sources of that area. It is observed that collection of raw fish from landing centers/markets (90\%) and own 10\%. In most cases, it was observed that low quality damaged fishes were brought from the local fish markets and landing centers for drying. The amount of collected raw fish depends on price and availability of raw fish.

\section{Transportation}

Transportation of raw fish from fish landing centers to fish drying point was mainly done by non-mechanized van, rickshaw, and bicycle or by head load or shoulder load of the labors. Dry fish was transported from drying point to wholesale market or arath by truck or train.

\section{Sorting}

Sorting is necessary step before drying. Sorting is done on the drying yard. Both male and female workers engaged for sorting of fish. The purpose of sorting was sorting of small and large fish, sorting out weeds, other particles, shorting fresh and rotten fish species. Sorting also practice after fish drying to separated fish according to the quality and size of the dried fish.

\section{Washing}

A primary washing is done after sorting. In most cases, dry fish farmers washed their raw fish with sea water as there was no fresh water in drying areas. It was also found that, many dry fish farmers/processors did not wash their raw fish. Final washing is done after scaling and degutting.

\section{Salting}

Use of salt is important for proper fish drying. Salt protect the dry fish from spoilage and ensure long time preservation. It was found that dry fish farmers used salt with raw fishes before drying. The rate of mixing salt in the study area was found as $1 \mathrm{Kg}$ salt for $12 \mathrm{Kg}$ of fishes. All the dry fish processor/fisherman used non-brand commercial salt for this purpose.

\section{Drying under the sun}

All the fishes are dried under sun. The process of drying varies according to the fish size and also some extent, choice of the consumers. For comparatively large scale fish drying, bamboo made rack of 1.05-1.2 meter high from earth is used in most cases. A bamboo splits made mat is used on the rack over which raw fishes were spread for drying. In some places fishes were spread on fishing seine nets directly on earth without using any bamboo.

\section{Drying duration}

Drying duration extremely varied with weather conditions like available sunlight, temperature, relative humidity, wind flow, raining status etc. In the surveyed areas, at normal weather condition (enough sunlight, temperature, humidity, and no rain) drying duration recorded to be varied from 2-6 days depending on the size of the raw fishes.

\section{Packaging}

After sorting, the dried fishes were bagged into a plastic and jute bag for easy handling. Sometimes bamboo baskets were also used for this purpose. The size varied with the quantity of the product to be stored. Sometimes the dried fish marketing use jute sacks and scaled. The fish drying farmers/processor use vacuum pack when they packed.

\section{Storage of dried fish}

A well storage system gives the product safe and quality. Storage of dried fish is found to be performed in a tent made of thin plastic sheet and bamboo splits. This tent is usually made in the place of fish drying. Bagged dried fishes were kept into these tents for temporary storage until marketing or selling to the local vendors. If any infestation was found during storage the stored product was again sun dried for 1-2 days and restored.

\section{Marketing of dry fish}

Assembling and marketing are the most important processes in the dry fish value chain. The marketing involves a range of activities like supply of packaging material to the processors, procurement and storage of processed products, and transportation to distant markets. In some cases, traders finance the small-scale dry fish processors for procurement of raw fish, hiring of labor, transportation, etc. The traders are well informed about the demand and prices of dry fishes in different wholesale markets of distant places. They also provide links between processors and wholesalers and disseminate information on the required quantity and quality of processed products in different markets and about the prevailing prices for different types of processed fishes.

\section{Marketing channel of dry fish marketing}

Dry fish processors sold most (90\%) dried fish to dry fish aratders. However, they also sold the rest of their fish to final consumers directly and through retailers (Fig1). About similar actors were found by a number of researchers $[14,16,17,18,19]$. Very few (2\%) of their fish went to suppliers who proceeded to the exporter. The aratders mainly sell to district-level wholesalers (67\%) who supply it to paiker cum retailers (28\%). Wholesalers (District level) sell only $7 \%$ to the final consumers. Dry fish aratders sell his product to the exporter with the help of supplier. Final consumers mainly bought dried fish from the paikers or retailers in addition to other actors.

The following value chains were identified in case of dry fish marketing (Fig 1)

Value chain-i: Dry Fish Processor/ Fisherman > Dry fish Arathdar $>$ Paiker cum Retailer $>$ Final Consumer

Value chain-ii: Dry Fish Processor/ Fisherman > local Retailer > Final Consumer

Value chain-iii: Dry Fish Processor/ Fisherman $>$ Supplier $>$ Exporter

Value chain-iv: Dry Fish Processor/ Fisherman > Dry fish Arathdar $>$ Supplier $>$ Exporter 
Value chain-v: Dry Fish Processor/ Fisherman $>$ Wholesaler

$>$ Retailer $>$ Final Consumer

Value chain-vi: Dry Fish Processor/ Fisherman $>$ Dry fish Arathdar $>$ Wholesaler (District level) $>$ Final Consumer
Value chain-vii: Dry Fish Processor/ Fisherman $>$ Dry fish $>$ Wholesaler (District level) > Paiker cum Retailer >Final Consumer

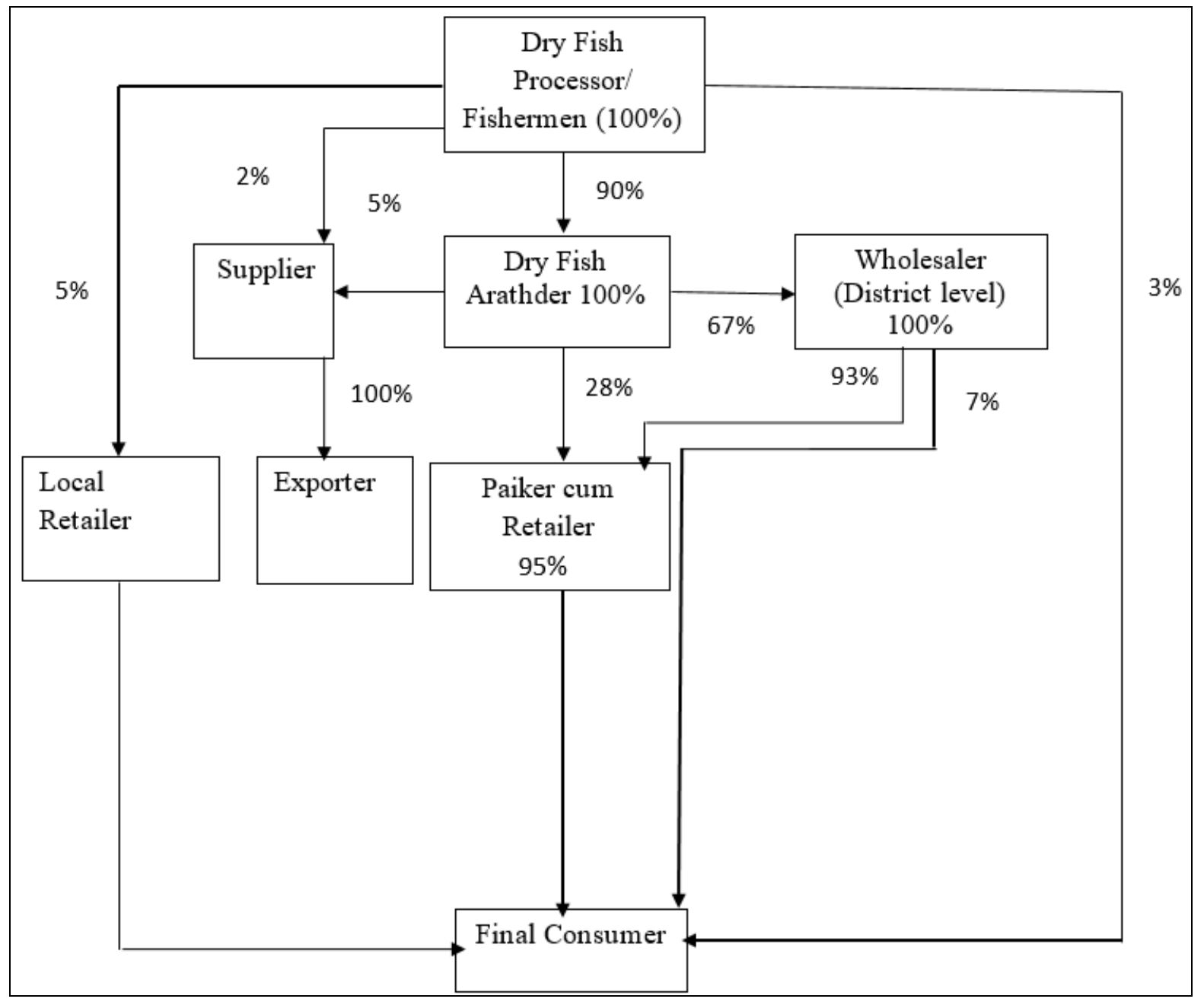

Fig 1: Marketing channel of dry fish marketing

Marketing Cost and Value Addition of dry fish of actor's in value chain

Table 1: Marketing cost of Traders of dry fish (Tk/Quintal)

\begin{tabular}{|c|c|c|c|c|}
\hline Cost Component & Dried fish processor Tk/Qt & Arathder Tk/Qt & Wholesaler Tk/Qt & Retailer Tk/Qt \\
\hline Permanent Labour & 168.00 & 21.23 & 0.00 & 0.00 \\
\hline Loading and unloading & 118.00 & 0.00 & 0.00 & 0.00 \\
\hline Rent of office and storehouse & 0.00 & 10.62 & 0.00 & 0.00 \\
\hline Electricity bill & 3.00 & 1.59 & 0.00 & 14.00 \\
\hline Mobile bill & 3.00 & 3.18 & 4.00 & 6.00 \\
\hline Market tool/rent & 0.00 & 0.00 & 0.00 & 22.00 \\
\hline Transportation cost & 209.00 & 0.00 & 61.00 & 11.00 \\
\hline Commission of Arthdar & 2317.00 & 0.00 & 1356.00 & 0.00 \\
\hline Commission of Local agent/faria/dalal & 590.00 & 0.00 & 0.00 & 0.00 \\
\hline Personal expenses & 27.00 & 6.37 & 8.00 & 8.00 \\
\hline License cost & 1.00 & 0.26 & 0.00 & 0.00 \\
\hline Ice cost & 30.00 & 0.00 & 49.00 & 36.00 \\
\hline Plastic/Bamboo basket & 15.00 & 0.42 & 7.00 & 1.00 \\
\hline Water & 0.00 & 0.00 & 0.00 & 7.00 \\
\hline Salt & 299.00 & 0.00 & 0.00 & 0.00 \\
\hline Security & 34.00 & 0.00 & 0.00 & 2.00 \\
\hline Weighing scale & 1.00 & 10.00 & 0.00 & 0.00 \\
\hline
\end{tabular}

Field survey (2019) 
Marketing cost for marine fish by different intermediaries Commission of arathder was highest (Tk 2317/Qt) among the cost items of dried fish processor where permanent labour cost was Tk 168/Qt. But the transportation cost of dried fish processor was Tk 209 per quintal and retailer transportation cost was Tk 11/Qt. The transportation cost varied from area to area depending on distance coverage. The per quintal average marketing cost of dried fish in different actors like dried fish processor for Tk.3942, arathder for Tk.53.68, wholesaler for Tk.1485 and retailer for Tk 110. Highest marketing cost was obtained by dry fish processor. The next highest marketing cost was obtained by wholesaler due to its high transportation cost and arathder commission (Table 1).Retailer marketing cost was the lowest (Tk 110/Qt) because they purchase the fish from local wholesaler or arathder and they sell the fish in the local market.

\section{Average prices of different species of dry fish}

Dry fish prices are vary from area to area and trader to trader. In coastal area the prices of dry fish is lower than other area, similarly dry fish prices is high when it is purchases from retailer than wholesaler. From the study we found that retailer sale dry fish at $10 \%$ higher rate than wholesale price.

Salmon fish price was the highest $(2000 \mathrm{Tk} / \mathrm{kg}$ ) among the different types of fish that are made for drying where sundori and loitta fish was convey lowest price (Less than $400 \mathrm{Tk} / \mathrm{kg}$ ). But (Figure 2) hilsha, shurma, tuna, bayin, koral, shrimp, rida, rupchanda, churi, kachki, taki, puti, baspata and lakka convey (456 Tk.kg, 722 Tk.kg, 1268 Tk/kg, 730 Tk.kg, 824 Tk/kg, 806 Tk/kg, 487 Tk/kg, $1628 \mathrm{Tk} / \mathrm{kg}, 756 \mathrm{Tk} / \mathrm{kg}, 500 \mathrm{Tk} / \mathrm{kg}$, $569 \mathrm{Tk} / \mathrm{kg}, \quad 450 \mathrm{Tk} / \mathrm{kg}, \quad 500 \mathrm{Tk} / \mathrm{kg}$ and $1600 \mathrm{Tk} / \mathrm{kg}$ ) respectively.

In the following figure showed the average prices of dry fish that was collected from the study area.

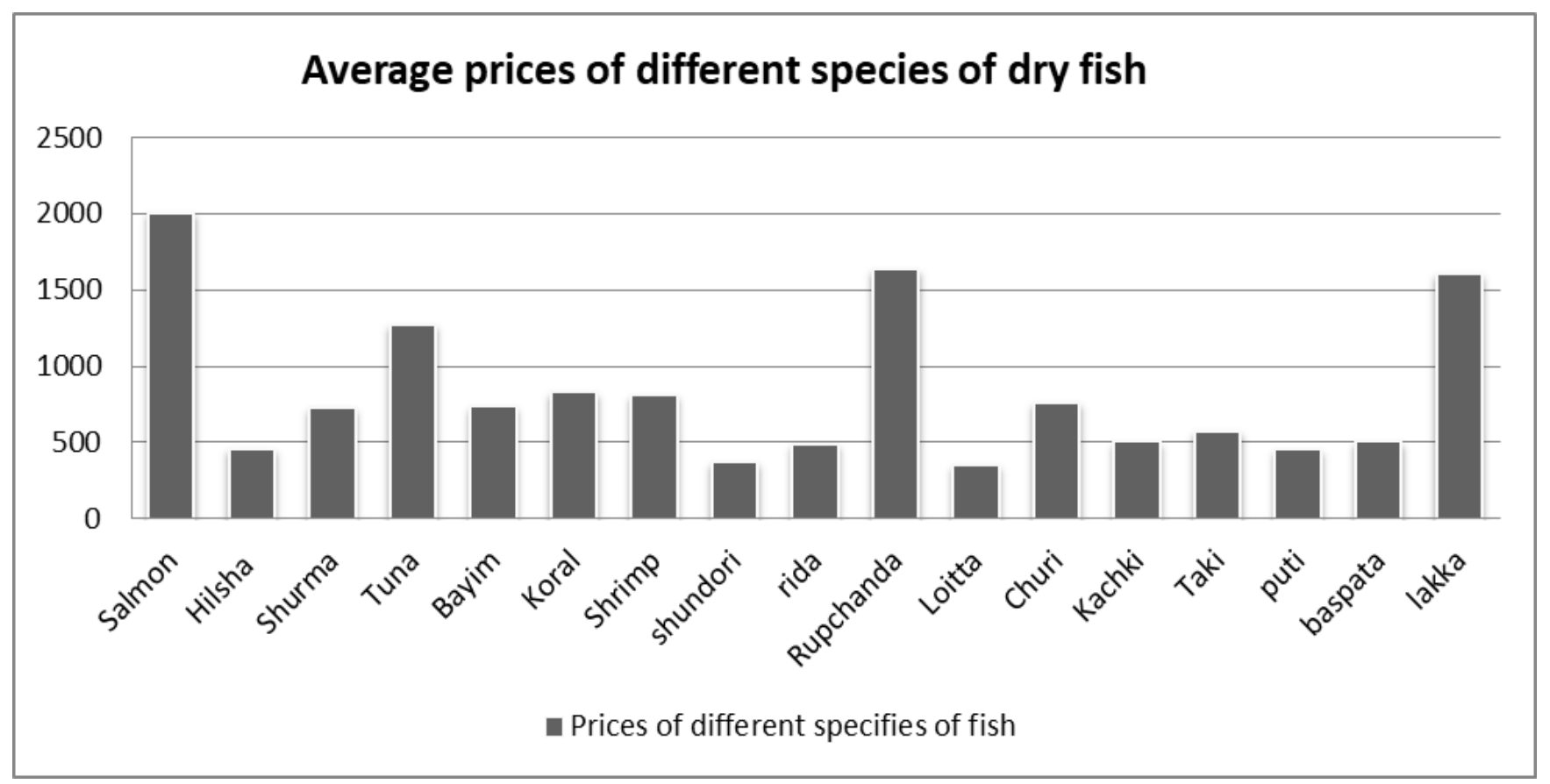

Fig 2: Average prices of different specifies of dry fish

Table 2: Value Addition of different intermediaries of marine fish (Tk/Quintal)

\begin{tabular}{|c|c|c|c|}
\hline Traders & Gross Margin & Marketing Cost & Value addition \\
\hline Processor (Drying) & 8877.00 & 3942.00 & 4935.00 \\
\hline Arathder & 1291.00 & 53.68 & 1237.32 \\
\hline Wholesaler & 3504.00 & 1485.00 & 2019.00 \\
\hline Retailer & 4972.00 & 110.00 & 4862.00 \\
\hline
\end{tabular}

Field survey (2019)

Value addition of different actors of dry fish involved in the chain

It was revealed from the study that the value addition of the dried fish processor, arathder, wholesaler and retailer were Tk.4935, Tk.1237.32, Tk.2019, Tk.4862 per quintal respectively. Among the intermediaries dried fish processor added highest value by processing the different fish and followed by retailer, wholesaler and arathder respectively (Table 2).
The average daily income of dry fish value chain actors Among the different stakeholder involved with fish drying, Arathder income was the highest (3000 Tk/day) among stakeholders. Other stakeholder's income was $1365 \mathrm{Tk} /$ day by wholesalers, $826 \mathrm{Tk} /$ day by dry fish processor, $500 \mathrm{Tk} /$ day by retailer, $300 \mathrm{Tk} /$ day by day labor and $200 \mathrm{Tk} /$ day by women and $100 \mathrm{Tk}$ /day by children. From the Table 3 we revealed that traders earn highest income but processor or who are related to direct involved in fish processing activities they earn less amount. 
Table 3: The average daily income of dry fish value chain actors

\begin{tabular}{|c|c|}
\hline Market actors & Daily income (Tk/day) \\
\hline Dry fish processor & 826 \\
\hline Arathder & 3000 \\
\hline Wholesalers & 1365 \\
\hline Retailers & 500 \\
\hline Women & 200 \\
\hline Day laborers & 300 \\
\hline Children & 100 \\
\hline
\end{tabular}

Field survey (2019)

\section{Conclusion}

Bangladesh has great opportunity to become one of the prevalent dried fish's producers in all over the world. Because it has many rivers, long sea shore area, efficient fishermen, competent dried fish's producer and better weather. But we have found different problems in this area. No arrangement has yet been made to scientifically process of dry fish and dry fish market in the coastal area. If the government or any private company takes the initiative, the biggest dry fish processing market of the country could be set up at coastal area. Financial problem is another problem. If government take necessary steps to solve financial complications through different government programmed and NGO's support then fishermen or dry fish processor will feel safe. Transport facilities are very much significant for the further development of this sector. So everybody should take necessary steps to provide institutional and organizational support, government support, extension services and more research along with knowledge of dried fish marketing for the development of dry fish marketing in coastal belt.

\section{References}

1. Nowsad AKM. Low Cost Processing of Fish in Coastal Bangladesh. Food and Agriculture Organization of the United Nations Bangladesh Representation Office Dhaka, Bangladesh 2004.

2. Reza MS, Bepary MAJ, Azimuddin KM, Nurullah M, Kamal M. Studies on the traditional drying activities of commercially important marine fishes of Bangladesh. Pakistan Journal of Biological Science. 2005;8(9):13031310.

3. Bogard JR. The contribution of fish to nutrition and food security: informing the evidence base for agricultural policy in Bangladesh. PhD thesis. Faculty of Medicine. The University of Queensland 2017.

4. BBS. Bangladesh Bureau of Statistics (BBS). Statistics \& Informatics Division (SID), Ministry of Planning, Government of the People's Republic of Bangladesh, Dhaka, Bangladesh 2020.

5. Cutting CL. The influence of drying, salting and smoking on the nutritive value of fish. In. Fish in Nutrition, Edition by Heen E Kreuzer R. Fishing News (books) Limited, London 1962.

6. Nowsad AKM. Participatory Training of Trainers: A New Approach Applied in Fish Processing 2007,328.

7. Marine SS, Hossain MA, Rashid A, Islam MA, Bari SM. Marketing strategies for dry fish in sylhet district of Bangladesh. Bangladesh Res. Pub. J 2014;10(2):151-169.

8. Patterson J, Ranjitha G. Qualities of Commercially and Experimentally Sun Dried Fin Fish, Scomberoidestol. African Journal of Food Science 2009;3(10):299-302.

9. Saha MK. A study on fish production technology in North-west Bangladesh.MS Thesis, Department of
Aquaculture, Bangladesh Agricultural University, Mymensingh 2003,71.

10. Nayeem MA, Pervin K, Reza MS, Khan MNA, Islam MN, Kamal M. "Marketing System of Traditional Dried and Semi-Fermented Fish Product (ChepaShutki) and Socio-Economic Condition of the Retailers in Local Markets of Mymensingh Region”, Bangladesh Research Publication Journal 2010;4(1):69-75.

11. Kleih U, Alam K, Dastidar R. Report of workshop on poverty alleviation and livelihood security among the coastal fishing communities - market and credit access issues. National Resources Institute (NRI) 2001, Reports No. 261394.

12. Purkait S, Sahu S, Arefin B, Pradhan SK, Sharma A, Boda S et al. Marketing Profile of Dry Fish in Digha Coast of West Bengal. Int. J. Curr. Microbiol. App. Sci 2018;7(10):3457-3470.

13. Mehtaj M, Das A. Challenges of Dry Fish Supply in Bangladesh: A Study on Chittagong Dry Fish Market, East African Scholars Journal of Economics, Business and Management 2018;1(1):27-33.

14. Faruque MO, Nazrul KMS, Tonny US, Islam KR, Dey SC, Mona SJ. Status of an Ideal Dry Fish Market of Bangladesh: A Study on Asadganj Dry Fish Market, Chittagong. International Journal of Life Sciences Biotechnology and Pharma Research 2012;1(3):214-225.

15. Haque SF, Iqbal MM, Hossain MAR, Hossain MA, Rahman MA. Value Chain Analysis of Dry Fish Marketing at Massimpur in Sylhet of Bangladesh. J. Sylhet Agril. Univ 2015;2(1):107-116.

16. Ahmed M, Islam N, Shamsuddoha. Value chain analysis in the dry fish production and marketing of post-harvest fishery products (PHFP) in the Coastal Belt of Bangladesh. Journal of Bangladesh Fisheries Research Forum 2007,87-112.

17. Flowra FA, Sen SC, Galib SM, Kamal MM, Islam SM. Dry Fish Marketing in Rajshahi and Thakurgaon, Bangladesh. International Journal of Biological Research 2010;1(5):13-16.

18. Rahman MM, Hossain MA, Fatematuzzhura, Tasnoova S, Ahamed F, Hossain MY et al. Fresh Fish Marketing Status in the Northwestern Bangladesh: Recommendations for Sustainable Management. Our Nature 2012;10(1):128-136.

19. Ali MM, Rahman MM, Hossain MY, Rahman MZ, Hossen MA, Naser SMA et al. Fish marketing system in southern Bangladesh: Recommendations for efficient marketing. Our Nature 2014;12(1):28-36. 